\title{
SELECTED PROBLEMS OF ASSESSMENT OF SUITABILITY OF RURAL AREAS FOR INVESTMENT ACTIVITIES ON AN EXAMPLE AN OPTIMAL LOCATION FOR PRODUCTION PLANT
}

\author{
Elzbieta Szafranko \\ University of Warmia and Mazury in Olsztyn, Poland \\ elasz@uwm.edu.pl
}

\begin{abstract}
Rural areas are increasingly often becoming attractive to investors. One obvious reason is the limited total area of land allocated to development in towns. Moreover, land parcels available for development in nonurbanised surroundings are less expensive. Rural areas lying in the proximity of towns are particularly appealing. However, the choice of a location that will satisfy the expectations of both the investor and future users of a planned building development depends on a number of factors, some of which can generate many problems. Thus, decision support methods can be useful when making a decision about the location of a building investment. This article contains a case of an analysis of available locations for the development of an industrial project in a rural area, which was conducted with two methods: multi-criteria analysis and graphic method.
\end{abstract}

Keywords: investment activities, rural area, location, assessment methods.

\section{Introduction}

Rural areas are defined as all land located outside administrative limits of towns. They make up most of Poland's surface area, same as in many other European countries. There are numerous functions and ways of using space in rural areas. These purposes are fundamental to the diversity of land use in the countryside. The land use structure outside cities and towns is dominated by farmland, while other types of land cover are forested land, surface water bodies, roads and railroads, housing developments, mines and wasteland. Because of a considerable share of land, which is either barren or not used intensively with respect to its principal function, more and more often developers consider buying land parcels in the countryside when planning new developments. Over the last years, many buildings have been raised on the outskirts of towns, especially along roads leading to these towns or their ringroads (Fig.1, 2).

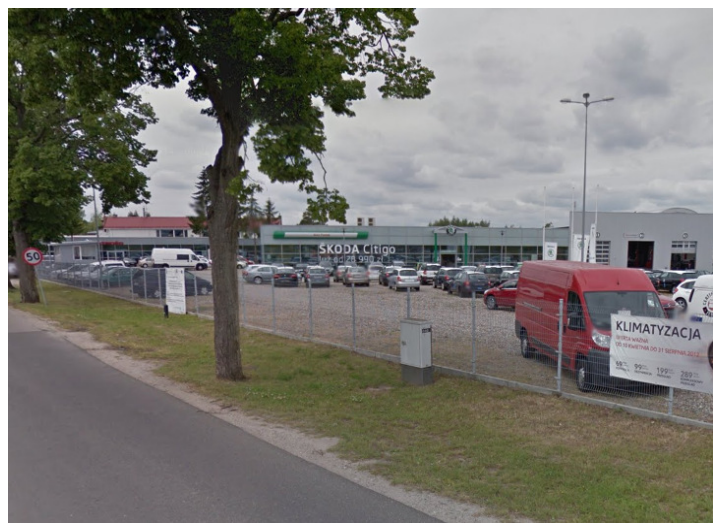

Fig. 1. Car showroom on the rural area

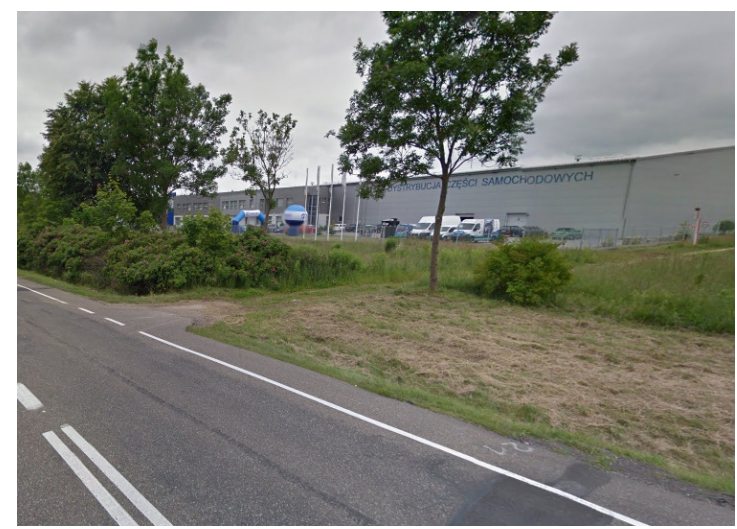

Fig. 2. Production hall on the rural area

Another reason why land outside the town limits is more attractive are its much lower prices, and the cost of land purchase could incur a large expenditure in the total costs of a building development $[1 ; 2]$. However, when considering a building investment on undeveloped land, certain drawbacks must be borne in mind. They are mostly connected with the technical infrastructure, which may be lacking in rural areas. This problem strikes many investors and is particularly grave when we are planning to build warehouses, industrial plants or large stores. These are all large-scale buildings, generating a high demand for amenities. Equally important could be the impact of planned buildings on the natural environment, which is often a source of formal and legal issues when a development is to be located outside the town limits [3;4]. The list of problems associated with making an optimal choice of location can be extended by adding the question of ground conditions, which are frequently unassessed in areas that until now have not been zoned for development [5; 6]. Additionally, undeveloped land in rural areas may not have ready zoning documents. Such a complicated situation 
that calls for taking into account many aspects necessitates the application of special tools to support the decision making process. Multi-criterial methods prove to be suitable because of the large number of decision factors. These are mathematical methods of a different degree of complexity, and their application requires the preparation of a big database about available locations and the identification of factors, which will determine the choice [7-9].

\section{The research objective and methodology}

The objective of this article is to discuss primary problems in evaluating land in rural areas as useful for industrial development. Such areas have very specific characteristics. To achieve the set aim, zoning documents as well as the data from the functional program of a planned building were analysed. The score analysis was applied to select an optimal location for the production plant. The choice was made dependent on six criteria dealing with technical and legal aspects, terrain, ecological problems, accessibility and, finally, logistics. The criteria were developed into indicators, which helped make an assessment. In our case study, five different locations were considered, out of which the most suitable one was chosen. The assessment of land parcel suitability was performed with one of the multi-criteria methods, i.e. score analysis, and supported by the graphic illustration approach.

For an evaluation of the degree to which the analysed locations satisfied the set criteria, an expertbased method was applied, where experts not only responded to surveys and questionnaires, but also provided more in-depth answers in an interview based on a previously prepared scenario.

\section{Case study}

The scientific experiment was based on the real case of industrial investment location. The research was carried out in the field and based on a literature and technical documentation. In order to make the best choice of a potential location, the so-called margin criteria, which a given site must fulfil, are defined. In our case they are as follows: no housing development on bordering land parcels, the minimum size of a land parcel 4.0 ha, the shape of a land parcel allows free positioning of the plant's infrastructure. Compliant to these assumptions, five possible locations for an industrial plant were found. They are all located outside the town limits.

For the sake of assigning scores to the potential locations of a future industrial plant, identical criteria had to be adopted for all the locations taken into consideration. The criteria were selected in such a way as to achieve a complex presentation of the analysed problem and, simultaneously, to ensure the highest possible objectivity. The criteria for the scoring analysis were: 1 - technical and legal; 2 - terrain specific; 3 - ecological; 4 - transportation and logistics; 5 - social; 6 - economic.

To achieve an objective and equal evaluation of all variants, apart from assessment criteria it is also necessary to determine indicators, which will serve the scoring analysis. Table 1 contains their list. Among the criteria mentioned above, the ones that deserve special attention are those, which are specific and connected with the type of the planned development. Because the planned production plant is to be built in a rural area, environmental criteria are extremely important. The indicators comprised within this group of criteria identify the current quality of the environment and presence of protected areas. The assessment also takes into account the possible impact of the development project on the analysed site. The transportation and logistics criteria are essential for the accomplishment of the development project and future exploitation of the manufacturing facility. The preferred transportation solutions are the ones, which facilitate the transport of raw materials and ready products.

The assessment of the identified variant locations was based on a scale from 0 to 3 points, where 0 stands for a negative assessment result, 1 - satisfactory, 2 - good, and 3 - very good. Expert opinions were collected when making the assessment of the degree to which the locations would fulfil the defined criteria. The results are shown in Table 2.

The assessment of the location variants, presented in this paper and involving the planned construction of a production plant in a rural setting, takes into account the specific character of this development. The choice of a location depended on the functional characteristics of the planned building. The range of possible land parcels was limited to those, which were 4.0 ha in size, had suitable land relief and were far enough from residential houses. Moreover, the choice of a suitable 
location was dictated by several other criteria. Within the defined criteria, several factors were distinguished, which were subsequently evaluated on a 4-degree scale.

Table1

\section{Specification of criteria and indicators}

\begin{tabular}{|c|c|}
\hline Criteria & Indicators for assessment \\
\hline $\begin{array}{l}\text { 1) technical and } \\
\text { legal }\end{array}$ & $\begin{array}{l}\text { 1.1. Legal status of a land parcel and the current land use } \\
\text { 1.2. Compliance with the local zoning documents } \\
\text { 1.3. Size of the land parcel } \\
\text { 1.4. Access to amenities (electricity, waterworks and sewers) } \\
\text { 1.5. Condition of access roads, accessibility of the terrain } \\
\text { 1.6. Possibility of temporal storage of waste generated by technological } \\
\text { processes }\end{array}$ \\
\hline 2) terrain & $\begin{array}{l}\text { 2.1. Possibilities of situating buildings and technical installations of the } \\
\text { production plant on the land parcel } \\
\text { 2.2. Geological conditions } \\
\text { 2.3. Hydrogeological conditions } \\
\text { 2.4. Distance from watercourses } \\
\text { 2.5. Additional tasks to perform to adjust the land for new purposes } \\
\text { (demolition, refurbishment of existing buildings, land levelling) }\end{array}$ \\
\hline 3) environmental & $\begin{array}{l}\text { 3.1. Condition of the natural environment } \\
\text { 3.2. Presence of nature protected areas } \\
\text { 3.3. Presence of areas protected as archeological or heritage sites }\end{array}$ \\
\hline $\begin{array}{l}\text { 4) transport and } \\
\text { logistics }\end{array}$ & $\begin{array}{l}\text { 4.1. Road network near the location, accessibility } \\
\text { 4.2. Distance to the nearest suppliers and buyers of the plant's products } \\
\text { 4.3. Presence of a railroad to facilitate transport }\end{array}$ \\
\hline 5) social & $\begin{array}{l}\text { 5.1. Distance to residential houses } \\
\text { 5.2. Potential approval by the local community } \\
\text { 5.3. Risk of social conflict } \\
\text { 5.4. Terrain surface configuration alleviating consequences of the plant's } \\
\text { operations }\end{array}$ \\
\hline 6) economic & $\begin{array}{l}\text { 6.1. Existing technical and transportation infrastructure, not requiring } \\
\text { refurbishment } \\
\text { 6.2. Land parcel does not require financial input to adapt it to the planned } \\
\text { function (demolition, refurbishment of existing buildings, land levelling) }\end{array}$ \\
\hline
\end{tabular}

Scores assigned to potential locations for the planned production plant

\begin{tabular}{|c|c|c|c|c|c|c|}
\hline Criteria & $\begin{array}{c}\text { Indicators for } \\
\text { assessment }\end{array}$ & $\begin{array}{c}\text { Location } \\
1\end{array}$ & $\begin{array}{c}\text { Location } \\
2\end{array}$ & $\begin{array}{c}\text { Location } \\
3\end{array}$ & $\begin{array}{c}\text { Location } \\
4\end{array}$ & $\begin{array}{c}\text { Location } \\
5\end{array}$ \\
\hline \multirow{6}{*}{$\begin{array}{l}\text { 1) technical and } \\
\text { legal }\end{array}$} & 1.1 & 3 & 2 & 1 & 2 & 1 \\
\hline & 1.2 . & 1 & 0 & 3 & 3 & 3 \\
\hline & 1.3 . & 3 & 2 & 3 & 3 & 3 \\
\hline & 1.4 & 2 & 3 & 3 & 2 & 3 \\
\hline & 1.5 . & 2 & 1 & 2 & 2 & 2 \\
\hline & 1.6. & 3 & 2 & 3 & 3 & 3 \\
\hline \multirow{6}{*}{ 2) terrain } & Sum: & 14 & 10 & 15 & 15 & 15 \\
\hline & 2.1. & 3 & 2 & 3 & 3 & 2 \\
\hline & 2.2 . & 2 & 2 & 2 & 2 & 2 \\
\hline & 2.3 . & 2 & 2 & 1 & 1 & 2 \\
\hline & 2.4 & 1 & 2 & 3 & 3 & 1 \\
\hline & 2.5 & 2 & 2 & 1 & 2 & 1 \\
\hline & Sum: & 10 & 10 & 10 & 11 & 8 \\
\hline
\end{tabular}


Table 2 (continued)

\begin{tabular}{|c|c|c|c|c|c|c|}
\hline Criteria & $\begin{array}{c}\text { Indicators for } \\
\text { assessment }\end{array}$ & $\begin{array}{c}\text { Location } \\
1\end{array}$ & $\begin{array}{c}\text { Location } \\
\quad 2\end{array}$ & $\begin{array}{c}\text { Location } \\
3\end{array}$ & $\begin{array}{c}\text { Location } \\
4\end{array}$ & $\begin{array}{c}\text { Location } \\
5\end{array}$ \\
\hline \multirow{3}{*}{ 3) environmental } & 3.1 & 2 & 3 & 1 & 2 & 2 \\
\hline & 3.2 . & 3 & 1 & 3 & 3 & 3 \\
\hline & 3.3. & 3 & 3 & 3 & 3 & 3 \\
\hline \multirow{4}{*}{$\begin{array}{l}\text { 4) transport and } \\
\text { logistics }\end{array}$} & Sum: & 8 & 7 & 7 & 8 & 8 \\
\hline & 4.1. & 2 & 1 & 1 & 1 & 2 \\
\hline & 4.2 . & 3 & 2 & 1 & 1 & 3 \\
\hline & 4.3 . & 3 & 0 & 0 & 0 & 3 \\
\hline \multirow{5}{*}{ 5) social } & Sum: & 8 & 3 & 2 & 2 & 8 \\
\hline & 5.1. & 2 & 2 & 2 & 1 & 1 \\
\hline & 5.2 . & 1 & 1 & 2 & 1 & 1 \\
\hline & 5.3 . & 2 & 1 & 2 & 1 & 1 \\
\hline & 5.4 . & 3 & 2 & 3 & 0 & 0 \\
\hline & Sum: & 8 & 6 & 9 & 3 & 3 \\
\hline \multirow{2}{*}{ 6) economic } & 6.1. & 2 & 1 & 1 & 1 & 2 \\
\hline & 6.2 . & 3 & 3 & 2 & 3 & 1 \\
\hline & Sum: & 5 & 4 & 3 & 4 & 3 \\
\hline & Total sum: & 53 & 40 & 46 & 33 & 45 \\
\hline
\end{tabular}

The results of the scoring analysis showed that location no 1 scored the highest for satisfying all the criteria. The second best location was land parcel 3, owing to the high scores it earned for the fulfilment of criteria 1,3 and 5. The third place was occupied by land parcel 5, which scored one point lower. The scoring analysis was complemented with a graphic analysis. The fulfilment of the set criteria by all the analysed variants is depicted in Fig. 3-7.

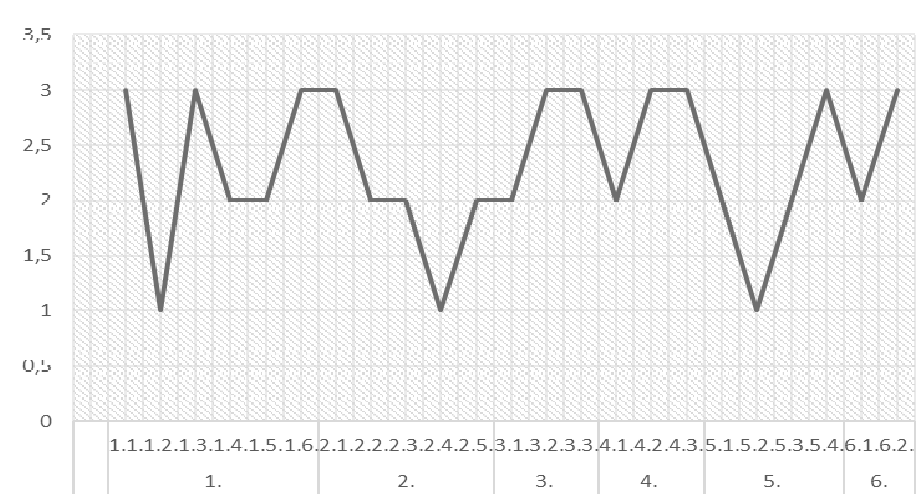

Fig. 3. Graphic illustration of scoring analysis - location 1

Location 2

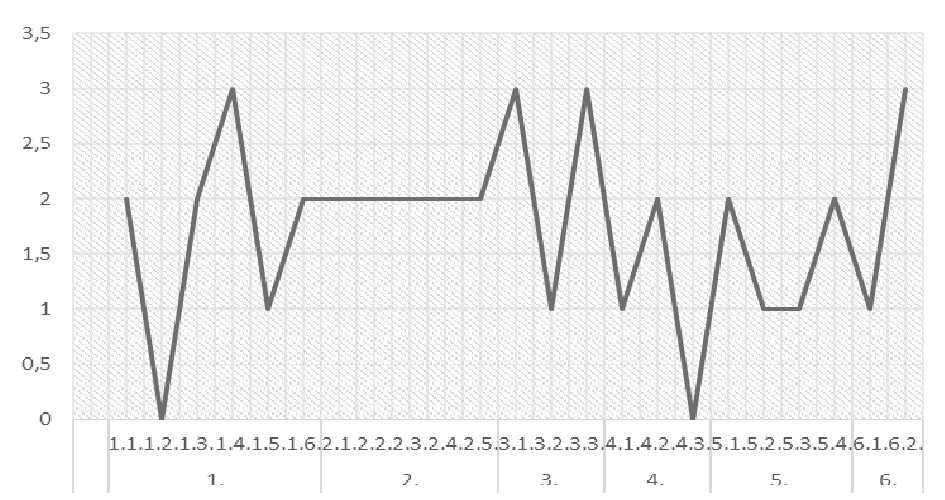

Fig. 4. Graphic illustration of scoring analysis - location 2 


\section{Location 3}

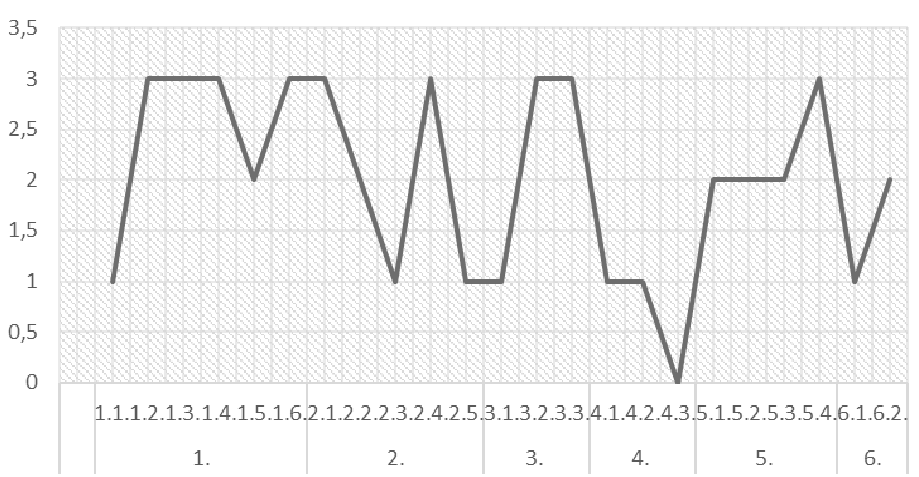

Fig. 5. Graphic illustration of scoring analysis - location 3

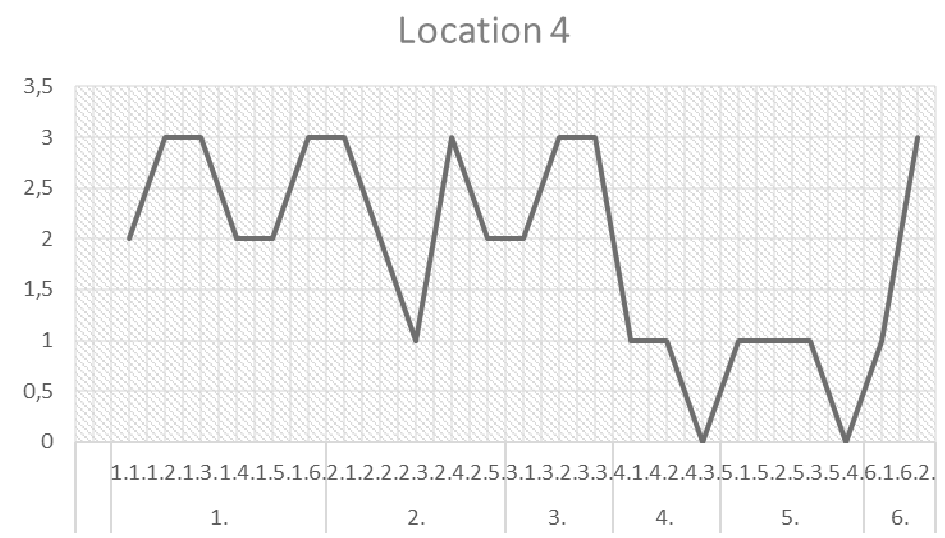

Fig. 6. Graphic illustration of scoring analysis - location 4

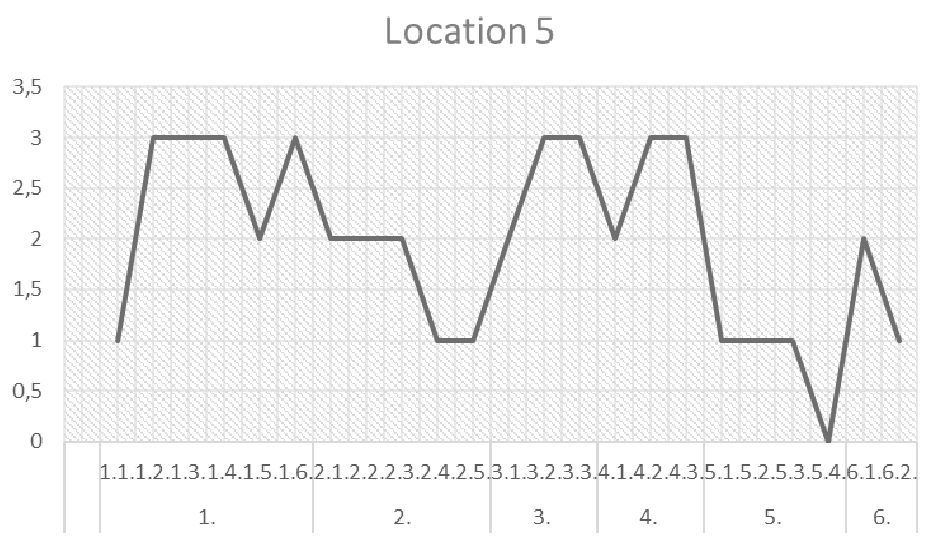

Fig. 7. Graphic illustration of scoring analysis - location 5

\section{Discussion of research problems and conclusions}

The areas where an optimal location of the planned production plant was searched for were situated outside the town limits. The investor opted for this solution because of the lower costs of purchase of land for development. When preparing input materials and data for the assessment, an analysis of the technical properties of the available land parcels was carried out. The zoning documents found in local government offices and organs of architecture and building supervision were included. A typical problem of undeveloped terrains is the lack of complete and updated zoning and planning documentation. Additional information was collected during field trips to chosen locations. However, the field observations sometimes proved to be difficult due to problems in identifying the exact location of particular land parcels and the associated infrastructure.

The specific features of rural areas create many problems to investors, but an opportunity of buying a land parcel for a fraction of the money it would cost in a town is often the prevalent 
argument. The analyses presented in this article demonstrate that there is huge potential that lies dormant in undeveloped land parcels located outside the town limits and confirm other research results published in the literature.

\section{References}

1. Godlewska-Majkowska H., Investment potential of the Polish rural areas, Business Administration Quarterly, No. 2 (23), April- June 2012, pp.5-30.

2. Kandilov, I. T., Renkow M., Infrastructure investment and rural economic development: An evaluation of USDA's broadband loan program. Growth and Change 41.2,2010, pp. 165-191.

3. Ding, Grace KC. Sustainable construction-The role of environmental assessment tools. Journal of environmental management 86.3, 2008, pp. 451-464.

4. Pawłowicz J. A., Influence of green areas on urban landscape, Technical Sciences, 13,2010, pp. 113-119

5. Reardon, Thomas, and Vosti. S. A., Links between rural poverty and the environment in developing countries: asset categories and investment poverty." World development 23.9,1995, pp. 1495-1506.

6. Szafranko E., Evaluation of a possible development of the transportation network in Poland supported by the EU funds, Olsztyn Economics Journal, 5/2, 2010, pp. 357-379.

7. Kim, S. H., Jang, D. H., Lee, D. H. and Cho, S. H., A methodology of constructing a decision path for IT investment. The Journal of Strategic Information Systems 9.1,2000, pp. 17-38.

8. Szafranko E., Application of the analytic hierarchy process (AHP) to evaluation of variants of a planned road investment project, Journal of International Scientific Publications: Materials, Methods \& Technologies, Volume 7, Part1, 2013, pp. 152 -164,

9. Szafranko E. Evaluation Of Variant Construction Projects Supported By Expert Opinion Systems Based On Multi-Criteria Methods, International Journal of New Technologies in Science and Engineering, Vol. 2, Issue. 5, 2015, ISSN 2349-0780, pp. 39-46 